\title{
Correction to: Postsecularity and the Poetry of T.S. Eliot, Stevie Smith, and Carol Ann Duffy
}

\section{Jane Dowson ${ }^{1} \mathbb{D}$}

Published online: 12 October 2021

(c) Springer Nature B.V. 2021

\section{Correction to: Sophia}

https://doi.org/10.1007/s11841-021-00849-1

In this article the title was incorrectly given as 'Living Without God: Multicultural Spectrums of the Atheist/Nastika: Postsecularity and the Poetry of T.S. Eliot, Stevie Smith, and Carol Ann Duffy' but should have been 'Postsecularity and the Poetry of T.S. Eliot, Stevie Smith, and Carol Ann Duffy'.

The original article has been corrected

Publisher's Note Springer Nature remains neutral with regard to jurisdictional claims in published maps and institutional affiliations.

The original article can be found online at https://doi.org/10.1007/s11841-021-00849-1.

\section{Jane Dowson}

jdowson@dmu.ac.uk

1 De Montfort University, Leicester, England, UK 